\title{
Praktik demokrasi dan kapitalisme di indonesia dewasa ini
}

\author{
Supriyadi ${ }^{\text {a,1*}}$, \\ ${ }^{a}$ Program Studi Pendidikan Pancasila dan Kewarganegaraan, Universitas Ahmad Dahlan, Yogyakarta \\ ${ }^{1}$ supriyadi@ppkn.uad.ac ${ }^{1}$ \\ ${ }^{*}$ korespondensi penulis
}

\begin{abstract}
ABSTRAK
Pada sistem demokrasi, pemerintah sebagai penyelenggara negara harus memperhatikan kepentingan rakyat. Kekuasaan politik di negara berpaham demokrasi tidak boleh dilaksanakan demi kepentingan penguasa, karena di dalam kekuasaan itu terkandung kepercayaan untuk melindungi kepentingan rakyat. Kapitalisme dapat hidup beriringan dengan demokrasi, karena keduanya berbasis kebebasan warga negara. Kapitalisme sebagai paham ekonomi yang berazaskan pemilikan individu, pasar, persaingan, dan profit memberikan keleluasaan gerak usaha. Indonesia adalah negara yang menganut paham demokrasi, tetapi secara konstitusional menolak kapitalisme. Dalam praktiknya, kemajuan demokrasi di Indonesia tak terhindar dari kapitalisme yang berimbas pada berbagai segi kehidupan yang dapat merusak demokrasi itu sendiri, akibat dari kepentingan sempit penguasa.
\end{abstract}

Kata kunci: format penulisan, jurnal, nasional, kewarganegaraan, abstrak

\begin{abstract}
In a democratic system, the government as a state organizer must pay attention to the interests of the people. Political power in a democratic state cannot be exercised in the interests of the authorities, because in that power, there is trust to protect the interests of the people. Capitalism can coexist with democracy, because both are based on the freedom of citizens. Capitalism as an economic understanding is based on the ownership of individuals, markets, competition, and profits provides flexibility for business operations. Indonesia is a country that embraces democracy, but constitutionally rejects capitalism. In practice, the progress of democracy in Indonesia cannot be avoided from capitalism which impacts on various aspects of life that can damage democracy itself, as a result of the narrow interests of the authorities.
\end{abstract}

Keywords: format penulisan, jurnal, nasional, kewarganegaraan, abstrak

Copyright (C2019 Universitas Ahmad Dahlan, All Right Reserved

\section{PENDAHULUAN}

Sejak memasuki masa reformasi, perkembangan kehidupan demokrasi (politik) di Indonesia mengalami kemajuan pesat, tetapi tidak diikuti secara paralel dengan tumbuhnya sistem ekonomi kerakyatan. Demokrasi yang memberikan kebebasan atau keleluasan dan partisipasi politik warga negara di Indonesia berkembang dan menunjukkan kemajuan luar biasa. Sistem pemerintahan maupun partisipasi politik relatif semakin membaik. Suksesnya beberapa kali pemilihan umum dan pers yang bebas, dapat menjadi salah satu indikasinya. Masyarakat internasional pun mengakui akan kemajuan demokrasi di Indonesia. Namun demikian, dalam kemeriahan demokrasi itu, ada terbetik gejala yang mengindikasikan kecenderungan demokrasi berbalik arah, yang barangkali suatu ketika dapat merusak demokrasi itu sendiri, dan bahkan dapat berakibat kurang percayanya rakyat dan bahkan masyarakat internasional kepada pemerintah. Seentara demokrasi politik berkembang pesat, tetapi tidak atau belum dikuti peningkatan kesejahteraan masyarakat secara merata. Rupanya, demokrasi berkembang tetapi ada kecenderungan mengerucut pada adanya fenomena-fenomena ketidakseimbangan hubungan antara penguasa dengan masyarakat. Seiring berkembangnya demokrasi, berkembang sistem kapitalisme, yang kemudian mampu memberikan corak kehidupan masyarakat bangsa ini secara menyeluruh. Berbagai dimensi kehidupan terkena imbasnya, tidak saja sistem ekonomi, bidang kehidupan lain pun terpengaruh pola dan gaya hidup kapitalisme. Banyak para pelaku utama penggerak demokrasi (penguasa) nampak tengah dilanda persoalan berkenaan kepentingan kekuasaan, yang kemudian berimbas pada semakin suburnya kapitalisme. Tulisan ini ingin mengungkap persoalan bagaimana perkembangan demokrasi keterkaitannya dengan cita-cita untuk terealisasi atau terwujudkannya kesejahteraan bagi semua beiringan dengan laju kapitalisme yang semakin tidak dapat dibendung.

\section{METODE}

Tulisan ini merrupakan hasil studi kepustakaan. Penulis mengamati fenomena perkembangan demokrasi dalam dinamika politik di Indonesia dalam kaitannya dengan dinamika perkembangan sistem ekonomi kapitalisme yang tengah melanda dunia, sehingga menyentuh 
berbagai dimensi kehidupan sosial dan bahkan segi kehidupan politik, tak terkecuali di Indonesia ini sebagai bagian dari studi sosial yang bersifat interdisipliner. Data didiskripsikan dan dianalisis menggunakan cara berfikir logis, dan kualitatif (induktif).

\section{HASIL DAN PEMBAHASAN}

Kapitalisme lahir dari paham liberal yang mengedepankan kepentingan individu sebagai segala-galanya. Sargent (Sargent, 2009) mengatakan bahwa tradisi liberalis sangat menekankan kemerdekaan individu. Istilah liberalisme erat kaitannya dengan kebebasan, dan titik berat pada kebebasan merupakan suatu garis utama dalam semua pemikiran liberal. Kaum liberal memandang masyarakat sebagai yang terbaik yang diatur oleh keseimbangan kekuatankekuatan yang berlawanan (Gerson, 2004). Kaitannya dengan kapitalisme, dikemukakan oleh Ebenstein, A, Ebenstein, W dan Fogelman (2000) bahwa secara historis perkembangan kapitalisme merupakan bagian dari gerakan individualisme. Gerakan itu juga menimbulkan dampak dalam bidang yang lain. Dalam bidang agama melahirkan reformasi; dalam hal penalaran melahirkan ilmu pengetahuan alam; dalam hubungan masyarakat memunculkan ilmu-ilmu sosial; dalam ekonomi melahirkan sistem kapitalisme. Karena itu peradaban kapitalis menjadi sah (memiliki legitimasi) adanya. Di dalamnya terkandung pengertian bahwa kapitalisme adalah sistem sosial yang menyeluruh, lebih dari sekadar suatu tipe tertentu dalam sistem perekonomian. Sistem ini berkembang di Inggris abad 18 dan kemudian menyebar luas ke kawasan Eropa Barat laut dan Amerika Utara. Kapitalisme dapat didefinisikan sebagai sistem sosial-ekonomi yang didasarkan pada modal swasta yang bercita-cita untuk memaksimalkan keuntungannya (atau, dengan kata lain, pada dominasi alat produksi swasta), dan pertukaran pasar bebas (Kolodko, 2018).

Pertumbuhan paham liberal di bidang ekonomi melahirkan kapitalisme, yang kemudian menciptakan suatu sistem ekonomi tersendiri. Secara lebih rinci beberapa sifat dasar yang mencirikan kapitalisme sejak awal perkembangannya. Sifat dasar atau ciri-ciri itu oleh Ebenstein, A, Ebenstein, W dan Fogelman (Ebenstein et al., 2000) dikemukakan sbb :

1) Pemilikan perorangan (individual ownership). Pemilikan alat-alat produksi (tanah, pabrik, mesin, sumber alam) dikuasai secara perorangan bukan oleh negara. Prinsip ini tetap mengakui adanya pemilikan negara yang berwujud monopoli yang bersifat alamiah atau menyangkut pelayanan jasa kepada masyarakat umum (kantor pos misalnya), tetapi hal tersebut lebih dianggap sebagai pengecualian daripada bagian dari pengaturan.

2) Perekonomian pasar (market economy). Perekonomian pasar dalam sistem kapitalis didasarkan pada spesialisasi kerja. Setiap orang hanya memasok sebagian kecil dalam memenuhi kebutuhannya melalui keterampilan dan pekerjaan pribadi. Dalam hal harga, penawaran dan permintaan menjadi kendala penentu, sejauh persaingan yang ada tidak diganggu oleh monopoli, oligopoly, dan usaha jenis atau industri tertentu.

3) Persaingan (competition). Dalam dunia industri riset telah menjadi bidang persaingan yang paling tajam. Riset hari ini berarti produk yang lebih murah dan lebih baik hari esok (1987: 151).

4) Keuntungan (profit). Perekonomian kapitalis memberikan lebih banyak kesempatan untuk meraih keuntungan daripada perekonomian yang lain karena dalam perekonomian kapitalis dijamin adanya tiga kebebasan yang biasanya tidak ditemukan pada sistem yang lain. Ketiga kebebasan itu adalah kebebasan berdagang dan menentukan pekerjaan, kebebasan hak pemilikan, dan kebebasan mengadakan kontrak.

Demokrasi adalah sebuah paham tentang sistem penyelenggaraan pemerintahan negara. Budiardjo (2008) mengemukakan istilah demokrasi berasal asal dari kata demos dan cratein (Yunani) yang berarti rakyat berkuasa atau government of the role by the people. Namun, menarik disimak konseptualisasi demokrasi yang pertama, demokrasi hanyalah "gerombolan yang memiliki aturan" (Crick, 2002). Di sisi lain, Plato menyerang konsep demokrasi ini sebagai aturan orang miskin dan bodoh lebih dari yang berpendidikan dan berpengetahuan. Namun demikian, Aristoteles membantahnya, bahwa pemerintahan yang baik adalah campuran unsur-unsur, yang sedikit memerintah dengan persetujuan banyak orang. Inilah yang menjadi cikal bakal aristokrasi (Crick, 2007).

Secara substantif William Ebenstein dan Edwin Fogelman (1987) mengemukakan bahwa dalam urusan pemerintahan yang memegang kekuasaan harus bertanggung jawab kepada masyarakat umum. Rakyat mempunyai kedudukan yang sangat penting. Pemerintah hanyalah agen rakyat. Kekuasaan politik di negara demokrasi tidak boleh dilaksanakan demi kepentingan penguasa. Di dalam kekuasaan itu terkandung kepercayaan yang tujuannya untuk melindungi kepentingan rakyat (1987: .153). Demokrasi memerlukan keterlibatan warga yang aktif yang berkompeten untuk menjaga checks and balances pada kehidupan demokrasinya (1990; Putnam, 2001; Putnam, Leonardi, Nanetti, 
\& Nonetti, 1993). Kompetensi mencerminkan kombinasi kompleks pengetahuan, keterampilan, pemahaman, nilai, sikap, dan keinginan yang mengarah pada tindakan manusia yang efektif dan diwujudkan di dunia dalam domain tertentu (Hoskins \& Deakin-Crick, 2010)

Demokrasi dapat dibedakan menjadi dua aliran. Tetapi diantara sekian banyak demokrasi ada dua kelompok aliran yang penting, yaitu demokrasi konstitusional dan satu kelompok aliran yang menamakan dirinya demokrasi, tetapi pada hakikatnya mendasarkan dirinya atas komunisme (Budiarjo, 2008). Dalam demokrasi konstitusional, aliran pikiran liberal dirumuskan dalam dalil: The list government is the best government (yang berarti pemerintahan yang paling sedikit adalah yang paling baik), atau dengan istilah Belanda staatsonthouding. Negara dalam pandangan ini dianggap sebagai Nachtwachterstaat (Negara Penjaga Malam) yang sangat sempit geraknya, tidak hanya di bidang politik tetapi terutama di bidang ekonomi. Kegiatan di bidang ekonomi dikuasai oleh dalil laissez faire, laissez aller, yang berarti bahwa kalau manusia dibiarkan mengurus kepentingan ekonominya masing-masing maka dengan sendirinya keadaan ekonomi seluruhnya akan sehat (Budiarjo, 2008). Paham bahwa ekonomi tidak diurus oleh pemerintah, tetapi diserahkan kepada individu warga negara inilah yang kemudian disebut sebagai sistem ekonomi kapitalisme. Kapitalisme berkaitan dengan globalisasi ekonomi. Secara sederhana, beberapa dimensi globalisasi ekonomi yang saling berhubungan, seperti (a) globalisasi perdagangan barang dan jasa; (2) globalisasi pasar keuangan dan pasar modal; (3) globalisasi teknologi dan komunikasi; dan (4) globalisasi produksi (Benczes, 2014).

Semakin menipisnya batas-batas geografi dari kegiatan ekonomi secara nasional maupun regional yang berbarengan dengan semakin hilangnya kedaulatan suatu pemerintahan negara muncul disebabkan oleh banyak hal, diantaranya adalah komunikasi dan transportasi yang semakin canggih dan murah, lalu lintas devisa yang semakin bebas, ekonomi negara yang semakin terbuka, penggunaan secara penuh keunggulan komparatif dan keunggulan kompetitif tiap-tiap negara, metode produksi dan perakitan dengan organisasi manajemen yang semakin efisien, dan semakin pesatnya perkembangan perusahaan multinasional di hampir di seluruh dunia (Sassen, 2006, 2007).

Di antara demokrasi dan sistem ekonomi kapitalis terdapat sisi kesamaan basisya, demokrasi berasaskan kebebasan individu warga negara, demikian halnya sistem ekonomi kapitalisme memiliki basis yang sama.) Ada hubungan antara kapitalisme dengan demokrasi. Kapitalisme sebagai sistem ekonomi mempunyai hubungan langsung dengan persamaan hak dan kebebasan. Persamaan kesempatan ditekankan. Ada pula keprihatinan akan kebebasan ekonomi, dalam arti bahwa tiaptiap orang bebas dan sama-sama mampu untuk memasuki pasar, dan berhasil atau gagal tergantung pada kemampuan dan keinginan konsumen serta kebutuhan akan produk atau jasa (Sargent, 2009).

Apakah sistem ekonomi kapitalisme selalu sejalan dengan demokrasi ? Kapitalisme memberikan kebebasan politik yang lebih besar dibandingkan dengan sistem lainnya. Jenis organisasi ekonomi yang memberikan kebebasan ekonomi secara langsung, yakni kapitalisme persaingan, juga mempromosikan kebebasan politik karena ia memisahkan kekuasaan ekonomi dari kekuasaan politik dan dengan cara ini memungkinkan yang satu menghapuskan yang lainnya (Ebenstein et al., 2000). Jadi sekalipun memiliki unsur yang sama diantara keduanya, dan kapitalisme memberikan kebebasan politik yang lebih besar, tetapi karena kedua sistem terpisah memungkinkan terjadinya suatu permasalahan yang dogmatis, yang satu meniscayakan atau merusak yang lainnya. Demokrasi dan kapitalisme sebagai sistem ekonomi mempunyai hubungan langsung dengan persamaan hak dan kebebasan sebagai dikemukakan di depan. teori demokrasi dan kapitalisme liberal ini membenarkan suatu tatanan sosial yang memberikan keuntungan materi dan kebebasan pribadinya dimenangkan (Wagner, 1987).

Demokrasi akan senantiasa berhadapan dengan aktivitas ekonomi. Kemajuan atau keberhasilan kapitalisme senantiasa diikuti oleh perombakan ciri kelembagaan dan ideologisnya yang asli melalui proses pemasyarakatan (collectivizing) kerangka kerja perusahaan. Proses pemasyarakatan perusahaan itu dalam era kapitalisme dirintis bukan oleh para pengritik kapitalisme tetapi oleh para pengusaha kapitalis yang sukses Lebih lanjut dikatakan, dalam dunia ekonomi situasi yang ada menunjukkan sifat yang berlawanan dengan konsep dasar demokrasi. Pimpinan perusahaan memegang kekuasaan yang berjangkauan luas atas para pemegang saham serta para pegawai atau pekerja, dan senantiasa membuat keputusan yang mempengaruhi kepentingan masyarakat tanpa batasan tanggung jawab yang jelas kepada masyarakat umum (Ebenstein et al., 2000). Ini berarti bahwa aktivitas ekonomi akan berdampak kepada demokrasi, bukan hal yang mustahil, karena pola perilaku pelaku usaha akan bekerja sesuai dengan prinsip kebebasan berusaha, bisa menjadi benalu melalui fungsi-fungsi politik dan mekanisme politik kepentingan rakyat (demokrasi). 
Indonesia menganut paham demokrasi yang berdasarkan Pancasila, dan masih dalam taraf perkembangan, mengenai sifat-sifat dan ciri-cirinya terdapat pelbagai tafsiran serta pandangan. Tetapi yang tidak dapat disangkal adalah bahwa beberapa nilai pokok dari demokrasi konstitusional cukup jelas tersirat dalam UUD 1945 (Budiarjo, 2008). Sementara itu, sesuai ketentuan konstusi Indonesia menolak atau tidak menerima sistem ekonomi kapitalisme, dan pula tidak mengembangkan paham Marxisme (komunisme), sebagai telah ditegaskan dalam pasal 33 UUD 1945 yakni mengembangkan sistem ekonomi usaha bersama (bukan individualisme).

Mengikuti realitas perkembangannya, banyak kasus yang berkaitan dengan demokrasi dan kapitalisme di Indonesia. Berikut beberapa kasus yang dapat dilihat sebagai contoh dinamika demokrasi yang diikuti berkembangnya kapitalisme, sehingga dapat merusak demokrasi itu sendiri, misalnya kasus korupsi KTP-elektronik; maraknya mini market yang kini terasakan menggeser telah pasar tradisional milik masyarakat; semakin mewabahnya korupsi di daerah. Pengaruh kapitalisme terasakan pula pada gerak perubahan masyarakat bidang ekonomi. Secara normatif kehidupan demokrasi di bidang ekonomi di Indonesia, adalah mengembangkan ekonomi sebagai usaha bersama berdasar asas kekeluargaan seperti ditegaskan dalam pasal 33 (1) UUD 1945. Dapat dipahami bahwa memang tidak mudah memaknai ekonomi sebagai usaha bersama, tetapi setidaknya pemerintah memiliki wacana dan acuan untuk pengembangannya. Usaha ekonomi bentuk koperasi, atau bentuk lainnya sebagai bentuk ekonomi kerakyatan, seperti pasar tradisional yang sering dicontohkan banyak orang sebagai model usaha yang sesuai pasal 33 (1). Atau sering orang memaknai pasal tersebut sebagai sistem sosialis. Tetapi terlepas dari makna tersebut, kebijakankebijakan politik bidang ekonomi yang dapat dirasakan masyarakat selama ini tidak cukup mengembangkan ekonomi yang bernuansa kerakyatan. Kapitalisme lebih terasakan, pasarpasar tradisional yang penuh dengan nilai-nilai usaha bersama, karena keuntungan-keuntungan tidak dimiliki seorang dua orang, melainkan terdistribusikan kepada banyak pedagang, dan sehingg golongan orang miskin pun mempunyai peluang memasuki pasar, sarat dengan nilai-nilai kekeluargaan, seperti terjadinya tawar menawar atas harga barang yang akan dibeli konsumen adalah bentuk-bentuk interaksi sosial yang mengembangkan toleransi, dsb. Tidak terakses secara baik. Isi pasl 33 (1) terasakan langsung dalam komunitas pasar tradisional dan koperasi. Tetapi model usaha ekonomi ini telah tergilas oleh gemerlapan kapitalisme, super maket, mini maket yang mematok harga pas tanpa bisa ditawar, orang miskin tak punya akses, semua keuntungan diraup pemilik modal perorangan adalah contoh kecil bentuk kesombongan dan egoisme pasar yang tidak terlukiskan sama sekali oleh para perancang pasal 33 UUD 1945. Tetapi apalah daya rupanya globalisasi membuat pasal-pasal indah menjadi berantakan. Pasar tradisional yang merupakan warisan sosial dan budaya bangsa kini semakin tergeser oleh maraknya supermaket, mini market, dan semacamnya.

Demikian halnya pada pengembangan demokrasi berkaitan dengan fungsi pejabat pembuat keputusan publik. Demokrasi yang secara ontologis harus bernilai keseimbangan (keadilan), yakni keseimbangan antara perilaku pemerintah dengan kepentingan rakyatnya, tetapi spirit demokrasi udah menjadi goyang dan berat sebelah ketika bersentuhan dengan penguasa yang punya kepentingan kekuasaan, terlebih bila di dalamnya ada sumber-sumber ekonomi. Demokrasi yang kini tengah berkembang dan mendapatkan angin segar dunia, terasa ternodai oleh bulir-bulir negatif kapitalisme. Kapitalisme memang ada di manamana ada dan tetap ada selama sektor ekonomi swasta lebih besar dari sektor publik, karena memiliki watak ibarat benalu, hidupnya dapat menempel pada siapapun penguasa yang menjadikan kukuasaan sebagai tujuannya.

\section{KESIMPULAN}

Ada kecenderungan bahwa perkembangan demokrasi di Indonesia yang sebenarnya selama ini telah diterima dan diakui masyarakat luas, tampak terbawa arus kekuatan ekonomi kapitalisme. Demokrasi yang mestinya berujung pada pemenuhan kepentingan rakyat banyak, kadang dihadapkan pada prgmatisme si pemilik modal perorangan (kapitalisme). Pemerintah yang mestinya sebagai pejuang demokrasi, sering menjadi tak berdaya, ada saja fenomenanya, baik legislatif, eksekutif, bahkan judikatifnya, termakan oleh gerusan arus kapitalisme, sejalan celotehan kaum pemilik modal (pengusaha kapitalisme) bahwa semua bisa dibeli, termasuk kekuasaan. 


\section{DAFTAR PUSTAKA}

Almond, G. A., Verba, S., \& Simamora, S. (1990). Budaya politik: tingkah laku politik dan demokrasi di lima negara. Jakarta: Bumi Aksara.

Benczes, I. (2014). The Globalization of economic relations. In The SAGE handbook of globalization (hal. 133-150). https://doi.org/10.4135/9781473906020.n 9

Budiarjo, M. (2008). Dasar-dasar ilmu politik. Jakarta: Gramedia Pustaka Utama.

Crick, B. (2002). Democracy: a very short introduction. Oxford: Oxford University Press.

Crick, B. (2007). Citizenship: The political and the democratic. British Journal of Educational Studies, 55(3), 235-248. https://doi.org/10.1111/j.14678527.2007.00377.x

Dian Fath Risalah. (2018). Kode Korupsi Tunjukkan Kecerdasan Pelaku. Harian Republika.

Ebenstein, A. O., Ebenstein, W., \& Fogelman, E. (2000). Today's isms: socialism, capitalism, fascism, communism, libertarianism. Prentice Hall.

Gerson, G. (2004). Liberalism, welfare and the crowd in J.A. Hobson. History of European Ideas, 30(2), 197-215. https://doi.org/10.1016/j.histeuroideas.20 04.01.001

Hoskins, B., \& Deakin-Crick, R. (2010). Competences for learning to learn and active citizenship: different currencies or two sides of the same coin? European Journal of Education, 45(1), Part II.

Kolodko, G. W. (2018). Socialism, capitalism, or Chinism? Communist and post-communist studies, 51(4), 285-298.

https://doi.org/10.1016/j.postcomstud.20 18.10.002

Putnam, R. D. (2001). Bowling alone: The collapse and revival of American community. New York: Simon and Schuster.

Putnam, R. D., Leonardi, R., Nanetti, R., \& Nonetti, R. (1993). Making democracy work: Civic traditions in modern Italy. In
The effects of brief mindfulness intervention on acute pain experience: An examination of individual difference (Vol. 1). https://doi.org/10.2307/2620793

Sargent, L. T. (2009). Contemporary political ideologies. In The Western Political Quarterly (14 ed., Vol. 22). https://doi.org/10.2307/446381

Sassen, S. (2006). Territory, authority, rights: from medieval to global assemblages (Vol. 53). https://doi.org/10.1017/CBO9781107415 324.004

Sassen, S. (2007). A sociology of globalization. New York: W.W. Norton \& Company, Inc.

Wagner, W. C. (Mike). (1987). Democracy and Capitalism: Property, Community, and the Contradictions of Modern Social Thought. Journal of Economic Issues, 21(1), 549-551. https://doi.org/10.1080/00213624.1987.1 1504646 